Çukurova Üniversitesi Mühendislik Mimarlık Fakültesi Dergisi, 35(1), ss. 227-240, Mart 2020

Çukurova University Journal of the Faculty of Engineering and Architecture, 35(1), pp. 227-240, March 2020

\title{
Şevli Yapılarda Jeoteknik Ölçüm ve Ölçüm Verilerinin Değerlendirilmesi (Şişli-İstanbul)
}

\author{
Veli KESKIN ${ }^{1}$, Sedat TÜRKMEN ${ }^{* 1}$ \\ ${ }^{l}$ Çukurova Üniversitesi, Mühendislik Fakültesi, Jeoloji Mühendisliği Bölümü, Adana
}

Geliş tarihi: 28.02.2020 Kabul tarihi: 15.05.2020

\section{$\ddot{O} \mathbf{z}$}

Bu çalışma, İstanbul İli Şişli İlçesi, Cumhuriyet Mahallesi, 144 pafta, 994 Ada, 14 parsel üzerinde yer alan çok katlı bir yapının derin temel kazısı sırasındaki jeoteknik ölçümleri içermektedir. Çalışmanın amacı, derin temel kazı çalışmalarının kontrollü sürdürülmesinde farklı ölçüm disiplinine sahip jeoteknik ölçüm aletlerinin birlikte kullanılarak, olası șev hareketlerinin ciddi boyutlara ulaşmadan saptanmasıdır. Proje kapsamında açılan sondajlarla kazı öncesi zemin hakkında bilgi elde edilmiş ve bu bilgilere göre güvenli kazı için gerekli jeoteknik ölçüm aletleri belirlenmiştir. Kazı çalışmaları başlatılmadan önce oluşacak şev yüzeyleri dikkate alınarak çalışma alanı E1kesiti ile başlayan ve E14 kesiti ile sonlanan enine kesitlere ayrılmıştır. Ayrılan her bir kesit üzerinde genişlik ve kazı derinliği dikkate alınarak jeoteknik ölçüm aleti yerleştirilmesi planlanmıştır. Çalışma alanında kazı derinliğinin en fazla olduğu kesitler E1, E2 ve E3 kesitleridir. Kazı çalışmalarına öncelikle kritik olarak görülen E1, E2 ve E3 kesit güzergahında başlanmıştır. Kazı esnasında zeminde meydana gelebilecek yatay yer değiştirmeleri saptamak amacıyla yapı yaklaşım sınırı göz önünde bulundurularak, E1 kesiti için şev gerisi ve kazık arkası olmak üzere derinlikleri $52 \mathrm{~m}$ ile $48 \mathrm{~m}$ olan inklinometre boruları yerleştirilmiş̧tir. Aynı sistemle E2 kesiti için 47,5 m, 39 m, E3 kesiti için 42 ve 35 m'lik inklinometre boruları yerleştirilmiştir. Yapılan inklinometre ölçümleri sonucuna göre ölçülen maksimum yer değiştirmeler E1 kesiti için $48 \mathrm{~mm}$ E2 kesiti için $55 \mathrm{~mm}$ ve E3 kesiti için 27,5 mm olarak ölçülmüştür. Çalışmalar yürütülürken şev duraylılığını sağlamak için iksa sistemleri kullanılmıştır. İksa sistemlerinin hareketliliklerini ölçmek amacıyla kuşak yapılarına her üç kesit için her 3 metre de bir adet 100 ton kapasiteli toplamda 39 adet yük hücresi yerleştirilerek iksa sistemlerindeki yük artışları ölçülmüsştür. Kesitlerde ölçülen en büyük yük artışı E2 kesitinde12,45 kN (1.245 ton) olarak ölçülmüştür. Yatay hareketliliği ölçmek amacıyla E1, E2 ve E3 kesitlerine 14 adet ekstansometre yerleştirilerek ölçümler yapılmıştır. Yapılan ölçümlerle ölçülen en büyük yer değiştirme E2 kesitinde $4 \mathrm{~mm}$ olarak ölçülmüştür. Ölçülen bu değer kesit için risk teşkil etmemiştir. Düşey yer değiştirmeleri ölçmek amacıyla üç kesite birer adet çok sensörlü manyetik oturma kolonu yerleştirilerek ölçümler alınmıştır. Yapılan ölçümler sonucu ciddi bir oturma gözlenmemiştir. Yapılan kazı çalışması boyunca risk teşkil edecek kütle hareketi E4 ve E5 kesitlerinde gözlemlenmiştir. Kazı derinliğinin 15,2 m ile 9,4 m arasında değişen bu kesitlerde kazı yönünde ciddi bir yer değiştirme tespit edilmiştir. Hareketin başlıca sebebi yüzey sularına bağlı ayrışmış birimler içindeki iksaların zemine tutunamaması olarak belirlenmiştir. Ölçülen maksimum yer değiştirmeler ise inklinometre ölçümlerinde E4 kesitinde $30 \mathrm{~mm}$, E5 kesitinde ise $21,5 \mathrm{~mm}$ olarak ölçülmüştür. Kesitlere yerleştirilen yük hücresi ölçüm değerlerine göre meydana gelen yük artışları E4 kesitinde $26,38 \mathrm{kN}$ (2,638 ton), E5 kesitinde ise $23,13 \mathrm{kN}$ (2,313 ton) ölçülmüsşür. Saptanan aşırı yer değiştirmeler dikkate alınarak bu kesitlerde iksa destek sistemleri güçlendirilerek hareket miktarı kontrol altına alınmıştır.

Anahtar Kelimeler: Jeoteknik ölçüm, Aletsel izleme, Eğimli kazılar, İstanbul, Şişli

*Sorumlu yazar (Corresponding author): Sedat TÜRKMEN, sturkmen@cu.edu.tr 


\title{
Geotechnical Measurement and Evaluation of Measurement Data in Slope Structures (Şişli-İstanbul)
}

\begin{abstract}
This study included the geotechnical measurements used throughout the deep foundation excavation of a multi-storey building located on Şişli district, Cumhuriyet District, 144 map, 994 Island and 14 plat in Istanbul. The purpose of the study is to identify possible extreme slope movements before reaching serious dimensions using geotechnical measuring instruments with different measuring disciplines together in the controlled continuation of deep foundation excavation works. The information about the soil before excavation was obtained with drilling within the scope of the project. Hence, the necessary geotechnical measurement tools for safe excavation were determined according to the information obtained. The study area divided into cross sections starting with E1 and ending with E14 considering the slope surfaces that may occur before the excavation works start. It was planned to place the geotechnical measurement tools onto each divided sections considering the width and excavation depth. The excavation depts were greatest for E1, E2 and E3 cross sections. Initially, the excavations have started along these sections accepted as critical ones. In order to determine the horizontal displacements that may occur on the ground during the excavation, inclinometer pipes have been placed for sections including the back of the slope and the back of the pile considering the construction approach limit. The pipes were with a depth of $52 \mathrm{~m}$ to $48 \mathrm{~m}$ for E1 cross section, $47.5 \mathrm{~m}$ and $39 \mathrm{~m}$ for E2 cross section, and $42 \mathrm{~m}$ and $35 \mathrm{~m}$ for E3 cross ection. The inclinometer measurements showed that the maximum displacement measures observed were $48 \mathrm{~mm}$ for E1, $55 \mathrm{~mm}$ for E2 and $27.5 \mathrm{~mm}$ for E3. Retaining systems were used to ensure the slope stability through the study. Load increases in the retaining systems were measured using load cells a capacity of 100 tons for each one and a total number of 39 placed in every 3 meters for each three sections. The greatest increase was measured as $12.45 \mathrm{kN}$ (1.245ton) in cross section E2. In order to measure the horizontal mobility, measurements were made by placing 14 extensometers in cross sections E1, E2 and E3. The largest displacement measured was observed as $4 \mathrm{~mm}$ in the E2 section. This measured value did not pose a risk for the section. In order to measure the vertical displacements, a multisensor magnetic settlement column was placed in three cross sections and measurements were taken. No serious settlement was observed as a result of the measurements. The mass movement which could pose a risk during the excavation work was observed in cross sections E4 and E5. A serious displacement in the direction of excavation was detected in these sections that the depth of excavation varies between 15.2 and 9.4. The main reason for the movement has been determined as the inability of the support systems in the weathered units to adhesion to the soil. The maximum displacements were measured as $30 \mathrm{~mm}$ in the E4 cross section and $21.5 \mathrm{~mm}$ in the E5 cross section. Load increases according to the load cell measurement values placed in the sections were measured as $26.38 \mathrm{kN}$ (2.638 tons) in the E4 cross section and $23.13 \mathrm{kN}$ (2.313 tons) in the E5 cross section. Taking into consideration the excessive displacements detected, the support amount is strengthened in these sections and the amount of movement is taken under control.
\end{abstract}

Keywords: Geotechnical measurement, Instrumental monitoring, Slope excavations, İstanbul, Şişli

\section{GİRiș}

Ülkemizde çok katlı yapılar ve bu yapılar için yapılan dik temel kazılarının yürütülmesinde jeoteknik izleme aletlerinin kullanılması oldukça yenidir. Bu tür yapıların temel boyutları büyük ve derindir. Temel yapıları oluşturulurken çoğunlukla kontrolsüz ya da tek ölçüm yöntemi kullanılarak temel kazısı yapılmaktadır. Temel kazılarının kısa sürede bitirilip üst yapıya geçilmesi ve zaman kazanmak amacıyla hızlı ve kontrolsüz kazılar yaygındır. Yapılan hızlı kazı/taşıma işlemleri 
esnasında kazı alanının jeolojik ve fiziksel özellikleri göz ardı edildiği için kazı derinliği arttıkça teknik sorunlar baş göstermektedir. $\mathrm{Bu}$ belirtiler uzman kişi veya kişiler tarafindan gözlenip ilgili ölçümlerin yapılmaması halinde stabilite sorunlarına bağlı ciddi kazalar meydana gelmektedir. Meydana gelebilecek en büyük sorun, uygun şev açısı verilmemiş kazı duvarlarının duraylılığını aşarak kütle hareketlerine sebep olmasıdır. Bununla birlikte yeraltı su seviyesi ölçümlerinin periyodik olarak yapılmaması, kütlesel hareketlerin ana etkenlerinden biri olan su etkisinin göz ardı edilmesine sebep olmaktadır. Derin temel kazı işlemlerinin günümüz teknolojisi ve yerleştirilen çeşitli jeoteknik ölçüm aletleri aracılığı ile kontrollü ve minimum riskle yürütülmesi olasıdır. Bu ölçüm aletleri, kazı alanın jeolojik/jeoteknik özellikleri göz önüne alınarak uygun şev yüzeylerine veya şev gerisi kütleler içerisine uzman kişiler tarafindan yerleştirilerek olası şev hareketlilikleri detaylı ölçülmektedir. Ülkemizin çeşitli bölgelerinde kütle hareketleri soncu meydana gelen kazalar, derin kazılarda ve kütlesel hareketlerin ölçülmesinde jeoteknik ölçümlerin ihmal edildiğini gözler önüne sermektedir. Yapılan bu çalışma derin kazı çalışmalarında şev hareketlerinin iki ve daha fazla hasas ölçüm aleti ile elektronik komutla eş zamanlı ölçülmesi verilerin internet yolu ile aktarılması açısından yurdumuzda benzeri projeler henüz yaygın değildir. Özaydın ve arkadaşları (2000) tarafindan [1] bölgede yapılan bilimsel çalışma ile İstanbul ve yakın çevresinde Paleozoik yaşlı Trakya Formasyonu temel kayaç olarak çok geniş alanlarda incelenmiştir. Aletsel ölçümlü temel kazı çalışmaları bu formasyon içerisinde yürütülmüştür. Formasyon detaylı olarak incelendiğinde kumtaşı, silttaşı ve kiltaşından oluştuğu görülmüştür. Önceki çalışmalarda bu birim Trakya Formasyonu olarak adlandırılmıştır. Bu kırıntılı sedimanları yer yer andezit ve diyabaz daykları kesmektedir. Çalışma alanı içerisinde deformasyonlar belirgin bir şekilde görülmektedir. $\mathrm{Bu}$ deformasyonlar sonucunda kıvrılma, kırılma ve değişik doğrultularda çatlak sistemlerinin geliştiğ gözlenmiştir. Keskin [2] yaptığı Yüksek Lisans tezinde ve Ulusal Mühendislik Jeolojisi ve Jeoteknik Sempozyumunda derin kazı temellerinde şev duraylılığının aletsel ölçümü ve ölçüm verilerinin değerlendirmesi konusunu incelemiştir [3].

\section{MATERYAL VE METOT}

\subsection{Materyal}

$\mathrm{Bu}$ çalışma, İstanbul ili Şişli ilçesi, Cumhuriyet Mahallesi, 144 pafta, 994 Ada, 14 parsel üzerinde yer alan çok katlı bir yapının derin temel kazısı jeoteknik ölçümleri boyunca sürdürülmüştür. $\mathrm{Bu}$ çalışma kapsamında kullanılan ölçüm aletleri ve bu aletlerden alınan jeoteknik ölçüm verileri değerlendirilmiştir.

Temel kazısı boyunca oluşturulan şevlerdeki hareketlilik, şev duraylılı̆̆ı açısından çeşitli jeoteknik aletler kullanılarak ölçülmüştür.

Temel kazısı ve jeoteknik alet yerleşim çalışmaları 4 kazı cephesi şeklinde yürütülmüştür. Oluşturulan kazı cepheleri 14 kesite ayrılarak her kesite ölçüm almak için inklinometre, manyetik oturma kolonu, ekstansometre, yük hücresi ve piyezometre, yerleştrilmiştir. Çalışma alanın kazı cepheleri ve jeoteknik ölçüm kesitleri (Şekil 2)'de verilmiştir.

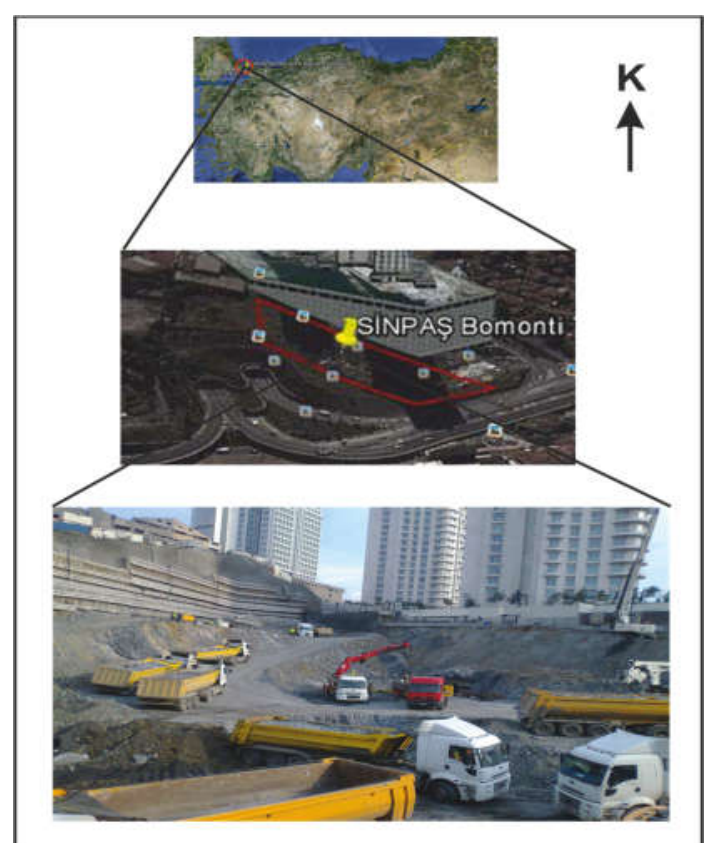

Şekil 1. Proje alanı ve çevresine ait yer bulduru 


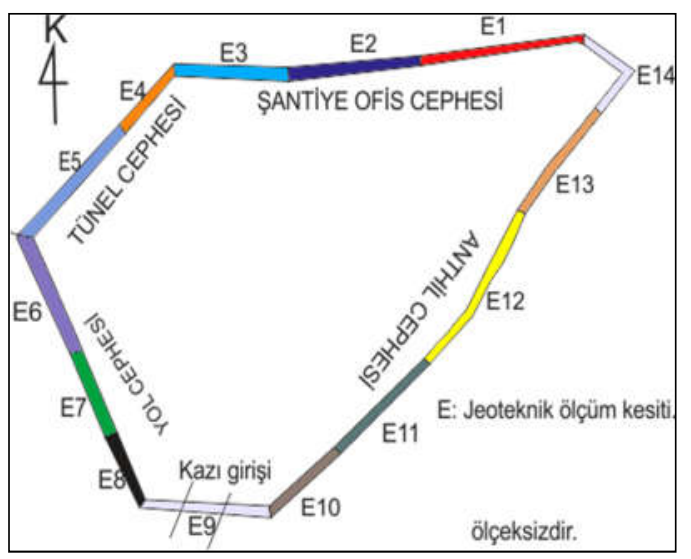

Şekil 2. Çalışma alanın kazı cepheleri ve jeoteknik ölçüm kesitleri

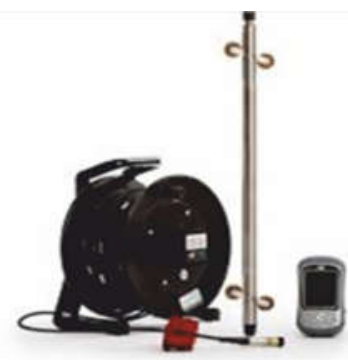

(a)

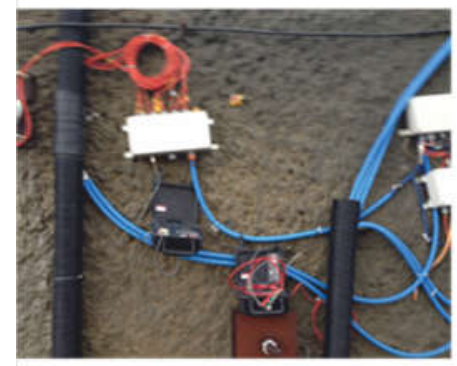

(c)

\subsection{Metod}

Proje kapsamında yerleştirilen jeoteknik ölçüm aletlerinden okuma almak için inklinometre kuyu okuma seti, piyezometre ve ekstansometre için vw2106 vibrating wire readout, yük hücresi için Sg350 readout, manyetik oturma kolonu ölçümü için düdüklü okuma aleti ve saha bilgisayarı cihazları kullanılmıştır [4] (Şekil 3a, 3b, 3c, 3d).

Projede yapılan çalışmalar arazi, laboratuvar ve büro olmak üzere 3 aşamada sürdürülmüştür.

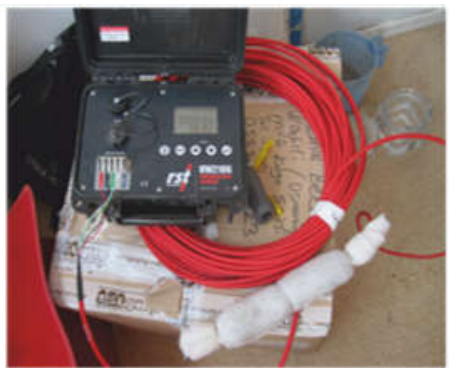

(b)

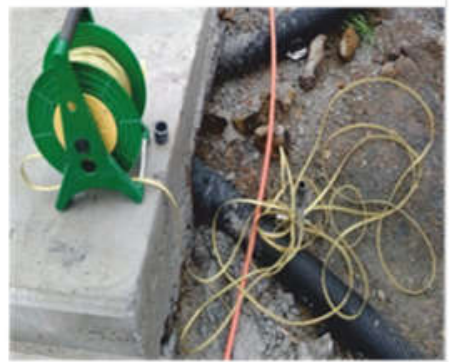

(d)

Şekil 3. İnklinometre (a), Ekstansometre (b), Yük hücresi, (c), Piyezometre (d) Aletleri

Proje alanındaki zeminlerin mühendislik özelliklerinin belirlenmesi amacıyla jeolojik ve jeoteknik etüt çalışmaları kapsamında derinlikleri $15-45.50 \mathrm{~m}$ arasında değişen, toplam derinliği ise 360.50 m olan 10 adet sondaj kuyusu açılmıştır. Alınan sondaj karotları üzerinde yapilan labatatuvar çalıșmaları ile çalışma alanının zemin koşulları belirlenmiştir [5]. Sahada yerleştirilecek olan ölçüm aletleri, saha ölçülerine göre aletlerin yerleşim föyleri ve etiketleri laboratuvar ortamında hazırlanmıştır. Yük hücresi ve ekstansometre aletlerinin kablolama kaynak işleri laboratuvar ortamında yapilırken ekstansometre tijleri ve inklinometre borularının hazırlanması için geniș alanlara ihtiyaç olduğundan bu tür hazırlıklar sahada sürdürülmüştür. Büro çalışmaları 
kapsamında arazi çalışmalarından elde edilen veriler değerlendirilmiş, arazide alınan bilgisayar ölçümleri ve gözlemsel ölçüm değerleri, elektronik ortamlara aktarılmıştır. $\mathrm{Bu}$ datalar kullanılarak gerekli çizimler, grafikler ve diyagramlar yardımı ile verileri analizleri yapılmıştır.

\section{PROJE ALANININ JEOLOJISI}

Proje kapsamında yapılan sondaja dayalı zemin ve temel etüt verilerine göre inceleme alanında en üstte 0-3 $\mathrm{m}$ arasında değişen dolgu birim, sonrasında Trakya formasyonuna ait ardalanmalı bir şekilde istiflenmiş şeyl, kumtaşı ve kiltaşı tabakaları incelenmiştir. Proje alanının genelleştirilmiş enine kesiti (Şekil 4)'te verilmiştir. Tabakların kalınlıkları saha genelinde farklılık göstermekte olup batı yönün de gidildikçe şeyl birimlerinin tabaka kalınlıkları artarken doğu yönünde ise kumtaşı tabaka kalınlıkları daha fazla gözlenmiştir. Sahanın batı kısmında yüzeyden itibaren dolgu birimin altında yaklaşık $5 \mathrm{~m}$ kalınlığında kumtaşı birimi bulunmakta, bu tabakanın altında şeyl tabakası yer almaktadır. Şeyl tabakasının kalınlığı sahanın doğusuna doğru azalmaktadır. $\mathrm{Bu}$ bölgede tabakaları daha çok kumtaşları oluşturmaktadır. Bu birimler arasında kalınlığı değişkenlik gösteren kiltaşı tabakaları görülmektedir [1,2].

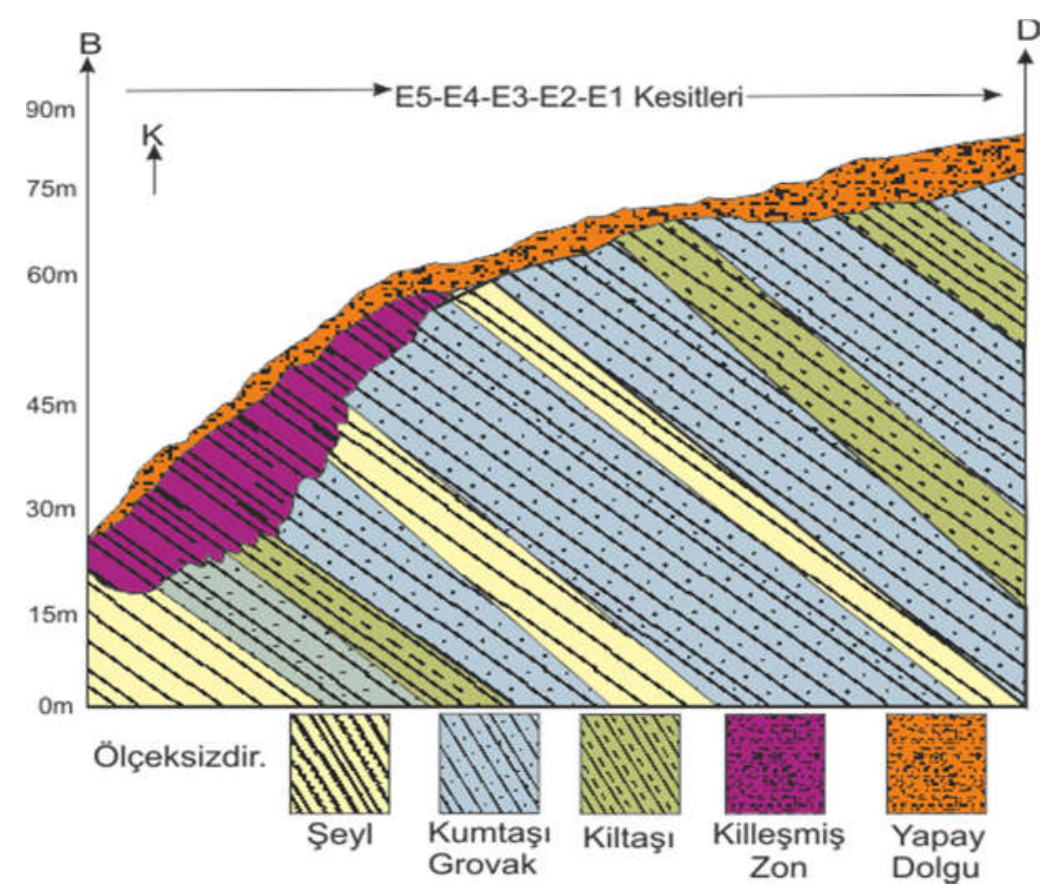

Şekil 4. Proje alanının genelleştirilmiş enine kesiti

\subsection{Jeoteknik Çalışmalar}

Proje alanının bütün kesitlerine delgi yapılarak veya ankraj uçlarına yerleştirilmiş jeoteknik ölçüm aletleri yardımı ile kazı başlangıcından itibaren seviye seviye şev duraylılığı ölçülmüştür. Yerleştirilen her ölçüm aletinden yerleştirildiği tarihten itibaren peryodik deneysel ölçümler yapılmıştır. Proje kapsamında yerleştrilen jeoteknik ölçüm aletlerine ait iksa yerleşim kesiti (Şekil 5)'te verilmiştir. Yapılan deneysel ölçümler düzenli olarak kayıt edilmiş artan kazı derinliği ve sayıca artan ölçüm cihazı verileri göz önüne alınarak kazı çalışmalarının kontrollü ilerletilmesi sağlanmıştır. 

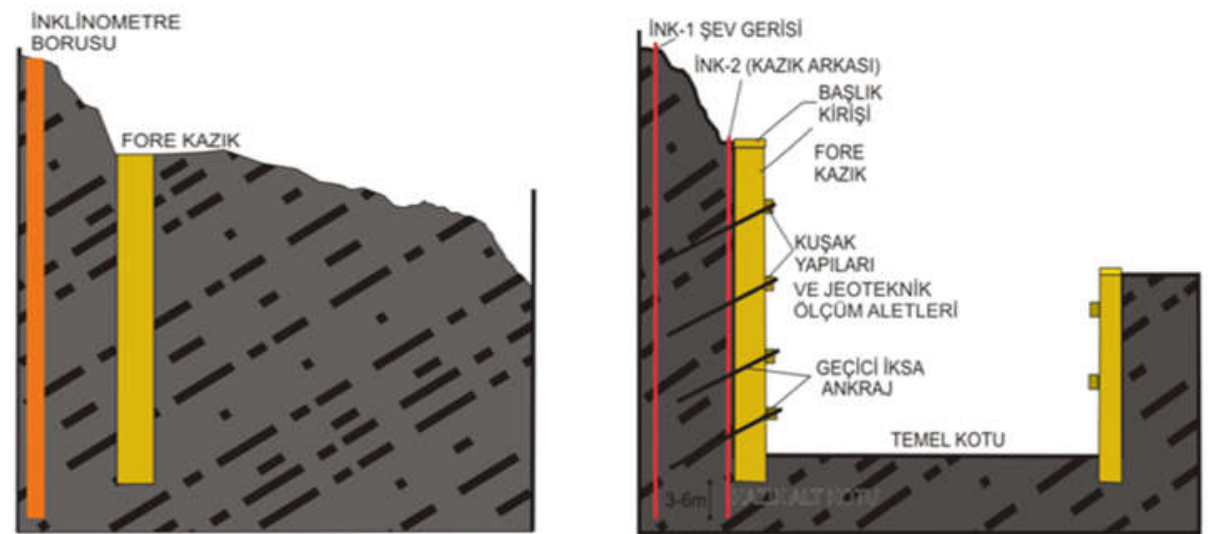

Şekil 5. Proje kapsamında yerleştrilen jeoteknik ölçüm aletlerinin iksa yerleşim kesitleri

\section{KULLANILAN ÖLÇÜM ALETLERİ}

JEOTEKNIK

\subsection{Inklinometre}

Teknik bilimlerde eğim açısı ölçer olarak bilinen inklinometre zemin ve kaya kütlelerinde doğal olarak oluşan veya insan eliyle inşa edilen mühendislik yapılarına bağlı olarak meydana gelen kütlesel hareketlerin ölçülmesinde kullanılan bir ölçüm aletidir [6]. Inklinometre aleti kullanılarak sondaj kuyusuna yerleştirilen inklinometre boruları yardımı ile sondaj kuyusunun eksenine dik yönde meydana gelen yer değiştirme ölçülmekte hareketin yönü, miktarı ve hızı belirlenebilmektedir İnklinometre yerleşim kesiti (Şekil 6)'da verilmiştir.

\section{INKLINOMETRE ÖLÇÜM SITEMININ ZEMINE YERLEŞTIRME AŞAMALARI}

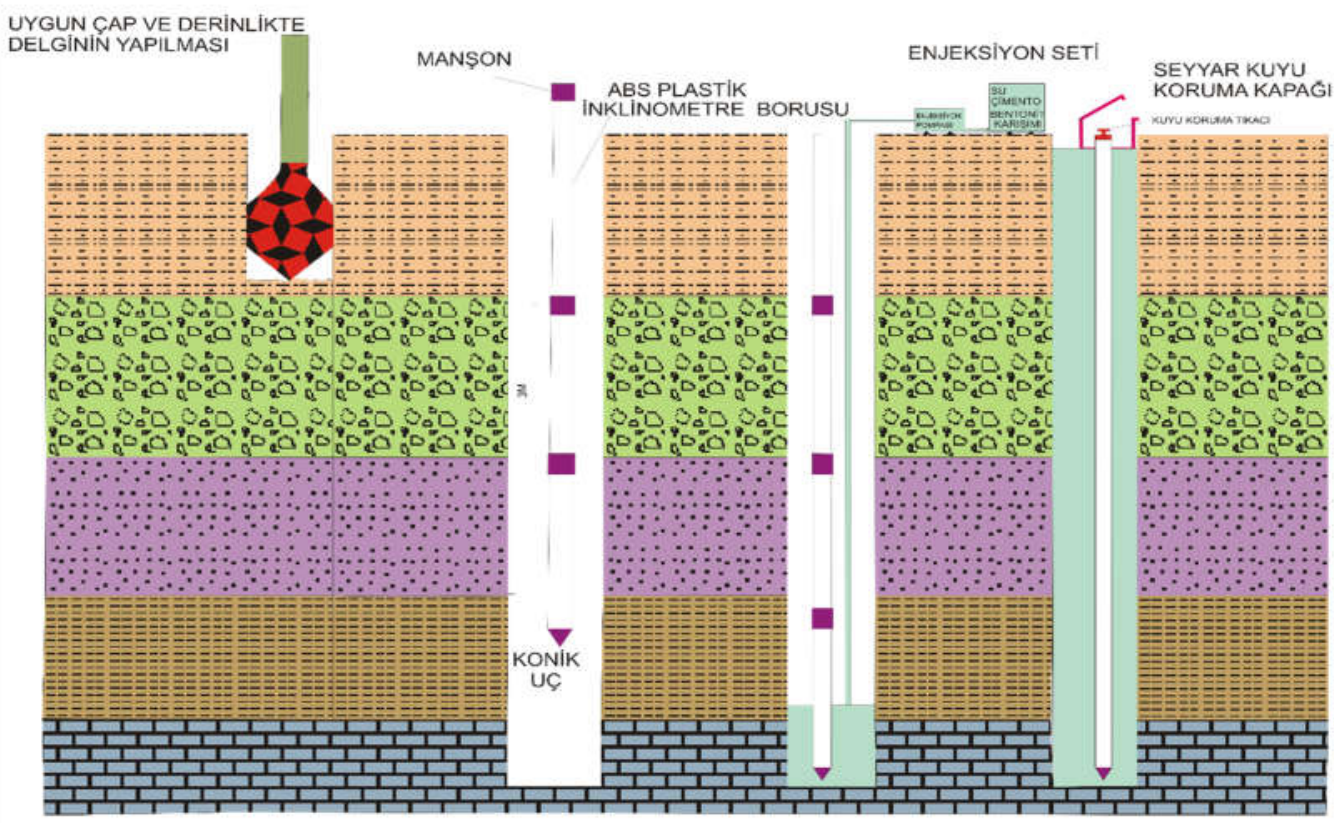

Şekil 6. İnklinometre yerleşim kesiti 
Bir tek alet seti kullanılarak birden çok sondaj kuyusundan ölçüm alınabilinmektedir. Ölçüm hassasiyeti diğer ölçüm aletlerinden daha yüksek olmasından dolayı zemin veya kaya kütlelerinde meydana gelen çok küçük hareketlilikler ölçülebilmektedir. Proje kapsamında şev gerisi ve kazık arkası olmak üzere aynı kesite iki adet inklinometre yerleştirilerek, kazı derinliğine paralel meydana gelen kütle hareketliliği ölçülmüştür. Ölçüm grafiği olan kümülatif deplasman grafiği (Şekil 7)'de verilmiştir [2].

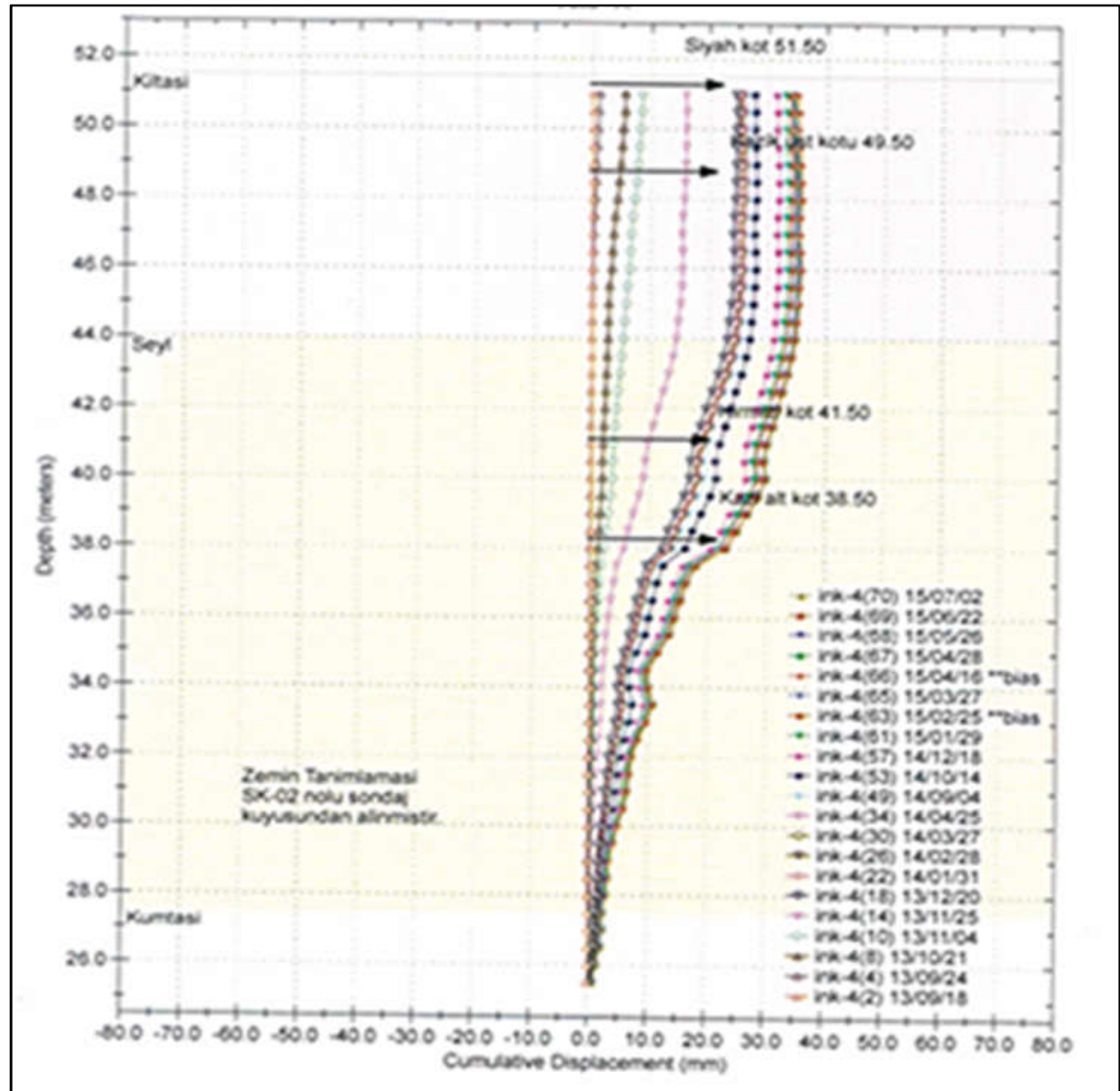

Şekil 7. Proje kapsamında yerleştirilen inklinomere verilerinden elde edilen kümilatif deplasman grafiği [2]

\subsection{Yük Hücresi}

Yük hücreleri ankraj uçlarına veya herhangi bir yük artışının beklendiği yapılara belirli bir yükle sabitlenen ölçüm aleti çeşididir. Yük hücrelerinin ankraj uçlarına belirli yükler altında sabitlenmesi ile ilgili görsel (Şekil 8)'de verilmiştir. Ölçüm prensibi yük hücresi içerisinde yer alan gliserin sıvısı içerisindeki gergin yayın artan kütle hareketliğine bağlı olarak meydana gelen genlik değişimlerinin $\mathrm{kN}$ veya $\mathrm{mv} / \mathrm{v}$ cinsinden ölçülmesi prensibine dayanır. Ölçümler (SG350 Readout) saha ölçüm cihazı kullanılarak alınmaktadır. (SG350 Readout) saha ölçüm cihazı şekil 9 da verilmiştir. $\mathrm{Bu}$ ölçümler ankrajlara gelen fazladan yükü belirlemek ve ya ankrajların yüklenip yüklenmediğiyle ilgili jeoteknik bilgi alınmasını sağlamaktadır. [2] 


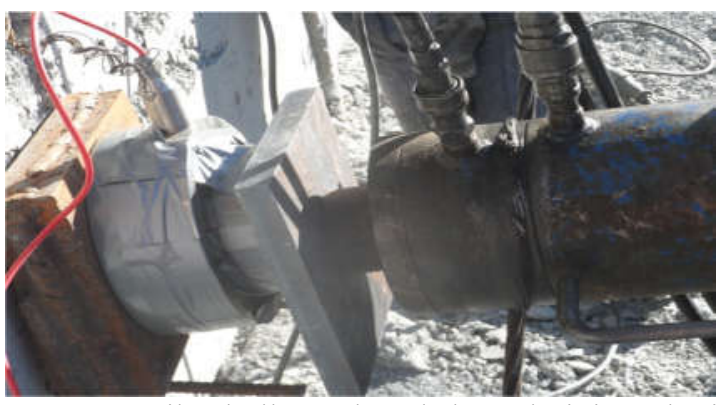

Şekil 8. Kriko kullanarak yük hücrelerinin ankraj uçlarına belirli yükler altında sabitlenmesi

Yerleştirilen yük hücreleri zaman içerisinde yük artışı gözleniyorsa bu yük artışı ankraj sistemlerinin tutmuş olduğu şev gerisi zemin kütlelerinde hareketliliğin meydana geldiğini veya geleceğini belirtir. Yük hücrelerinde yük azalması gözleniyor ise bu durum ankraj enjeksiyonunun sorunlu olduğunu zemine tutturulmadığını gösterir [2]. Aynı kesite farklı kotlara yerleştirilmiş birden çok yük hücresinden elde edilen veriler analiz edilerek bir proje kazısı boyunca şev duraylılık hakkında detaylı jeoteknik bilgi elde etmek mümkündür

Yük hücresi ölçüm verileri ile oluşturulmuş yükzaman grafiği (Şekil 10)'da verilmiştir. Bu kapsamda proje alanında kazı kesitlerine yük hücreleri yerleștirilmiştir. Yük hücreleri kazı derinliğine paralel olarak oluşturulan fore kazık kuşakları içerisinden zemin içerisine enjeksiyonla tutturulmuş, ankraj uçlarına belirli yüklerle yerleştirilmiştir.

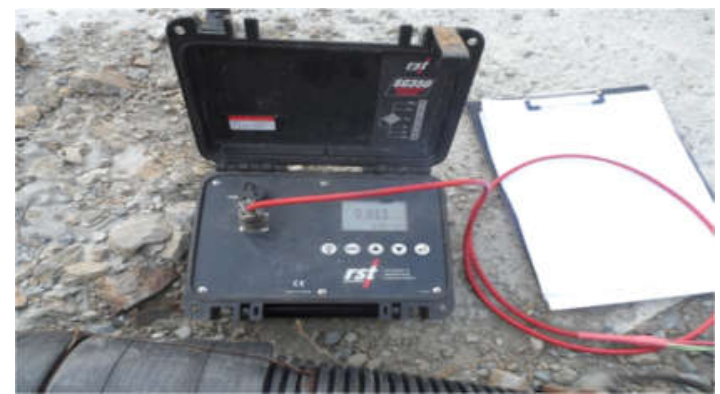

Şekil 9 Yük hücresi ölçüm aleti (SG350Readout)

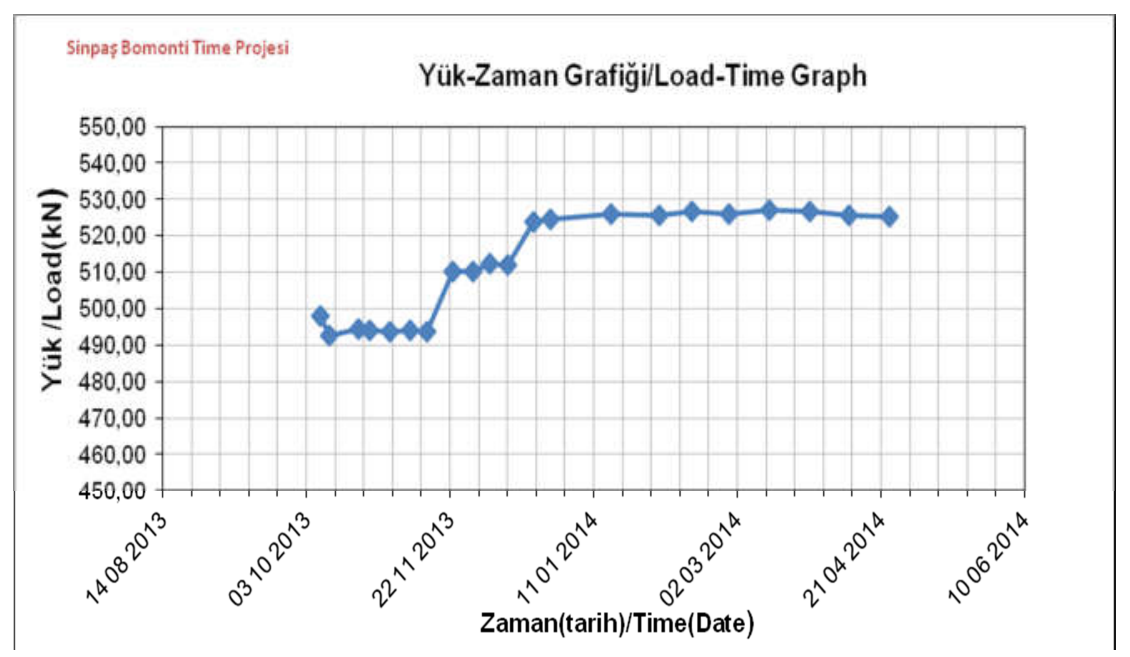

Şekil 10. Yük hücresi ölçüm verileri ile oluşturulmuş yük- zaman grafiği

\subsection{Ekstansometre}

Doğal şevler veya insan eliyle oluşturulmuş kazı şevlerinde olası kütle hareketini, kayan kütlenin kayma yüzeyini, kayma yüzeyinin şev yüzeyinden olan yatay uzaklığının tespiti için kullanılan ölçüm aleti çeşididir (Şekil 11). Bu aletle kayma riski taşıyan veya kontrollü şev kazılarında kontrol amaçlı yatay delgi ile zemin içerisine enjeksiyonla tutturulmuş tijler yardımı ile zeminde meydana gelebilecek kütle hareketleri ölçülmektedir. Kütle hareketi başladığında zemin içerisine tutturulmuş ekstansometre tijleri uzayarak veya kısalarak hareketlilik hakkında veri sağlamaktadır. 
Ölçüm prensibi gerilme altında sensörün uzayıp kısalmasına bağlı olarak titreşim genliğinin değişmesidir. Okuma alınırken saha bilgisayarı ile ekstansometreye mv/v birimi ile enerji yollanarak, gerilerek incelen veya kısalarak kalınlaşan sensör titreştirilir. Kalınlaşan sensörün titreşimine harcanan enerji büyük iken incelen sensör için harcanan enerji daha az olmaktadır.
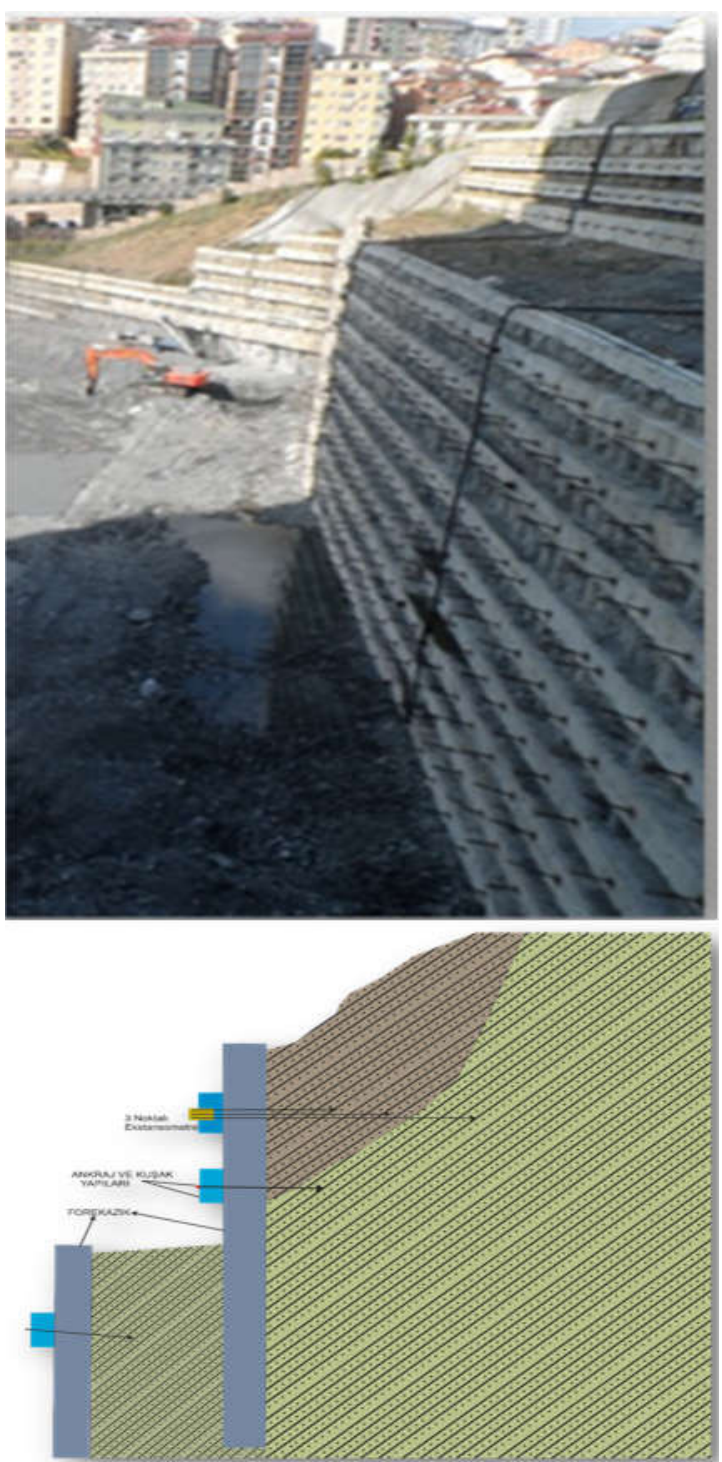

Şekil 11. Ektansometre yerleştirilmiş kazı yüzeyi ve yerleşim kesiti
Titreşim için harcanan enerji ölçülerek grafiklere aktarılarak $\mathrm{mm}$ cinsinden zemin hareketliliği hakkında jeoteknik veriler elde edilir. Yapılan ekstansometre ölçümlerine ait grafikler (Şekil 13 ve 14)'te verilmiştir. Hareket beklenen zemin içerisine tutturulmuş tijler ile hareket beklenen zemin içerisinden geçirilerek duraylı zemine tutturulmuş tijlerden alınan okumalarda artış veya azalış gözlenmektedir [2]. Hareketli kütle içerisinde kalan tijlerin ölçüm değerleri artarken hareket dişına tutturulmuş tijlere ait ölçüm değerleri azalma göstermektedir. Kayma düzlemi yük alan tijlerle yük kaybeden tijler arasından geçtiği bu ölçümlerle belirlenmektedir. Proje kapsamında bu amaçla E1, E2, E3 kesitlerinin belirli kademelerine çok sensörlü ekstansometreler yerleştirilerek şevlerde meydana gelebilecek hareketler ölçülmüştür. Ölçüm verileri grafiklere aktarılarak analiz edilmiştir.

\subsection{Manyetik Oturma Kolonu}

Manyetik oturma kolonu zeminlerde düşey yöndeki oturma miktarını ölçmek için kullanılan bir ölçüm aletidir. Açılan düşey sondaj kuyusu içerisine inklinometre borularının dış yüzeyine monte edilerek ya da herhangi bir borulama sistemi kullanılarak zemin içerisine belirli aralıklarla yerleştirilir. Yerleştirilen derinlikler ölçülerek kayıt edilir [2].

Yerleştirilen magnetlerin enjeksiyon yardımı ile zeminin bir parçası gibi davranması sağlanır, böylelikle zeminde meydana gelen oturma ile birlikte magnetlerde hareket eder. Düdüklü manyetik oturma ölçer yardımı ile bu oturma miktarı ölçülerek ilk okumalarla arasındaki farklar bulunur. Bulunan bu fark değeri zeminin oturmasıyla ilgili bilgi elde edilmesini sağlar. Proje kapsamında manyetik oturma kolonları ofis cephesinde yer alan E1, E2, E3 kesitlerine yerleştirilmiştir. Manyetik oturma kolonu ile ilgili yerleşim çizelgesi ve ölçüm grafiği (Şekil 14 ve Şekil 15)'te verilmiştir. 


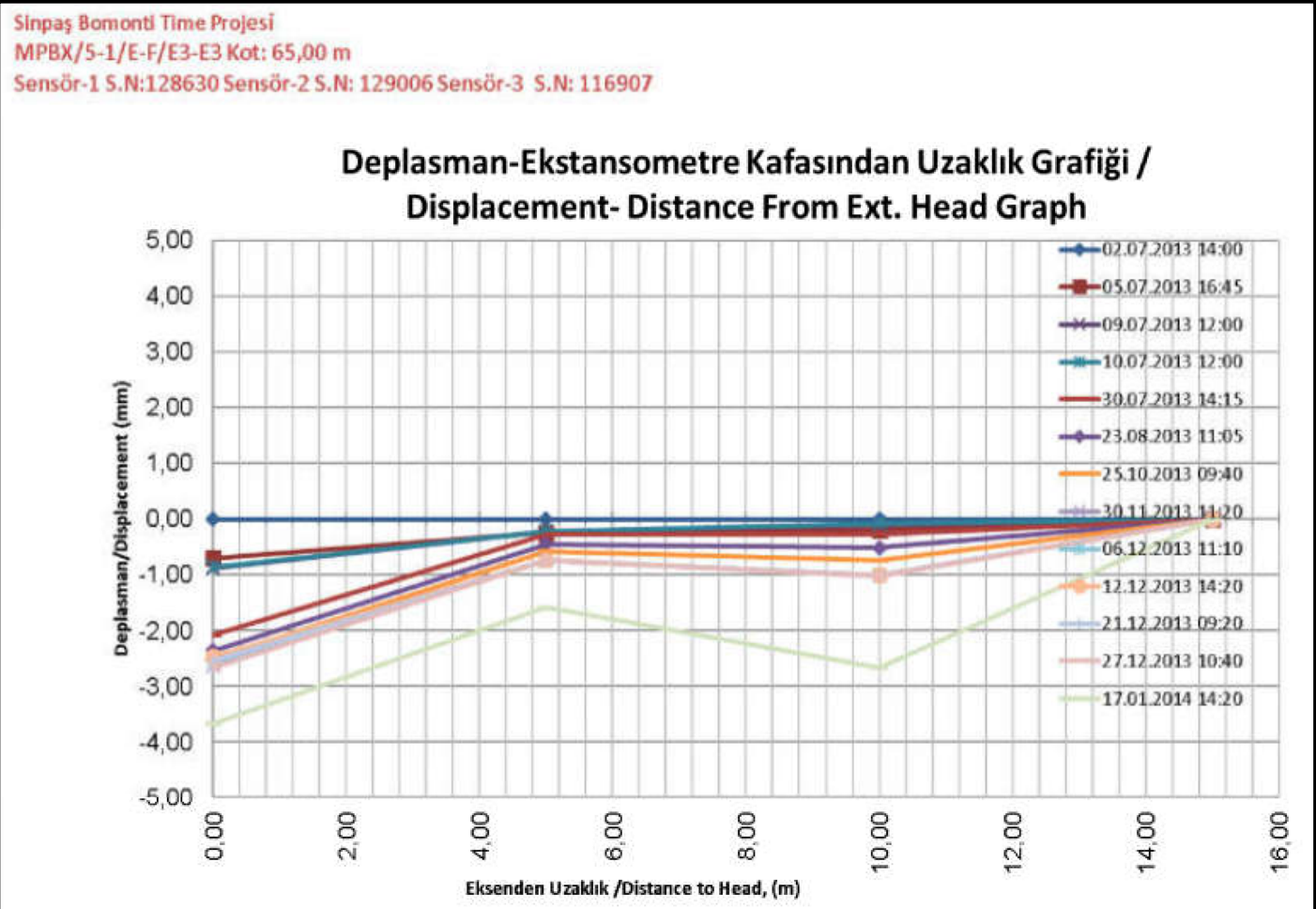

Şekil 12. Ekstansometre verilerinden elde edilen hareket noktası kazı yüzeyi grafikleri

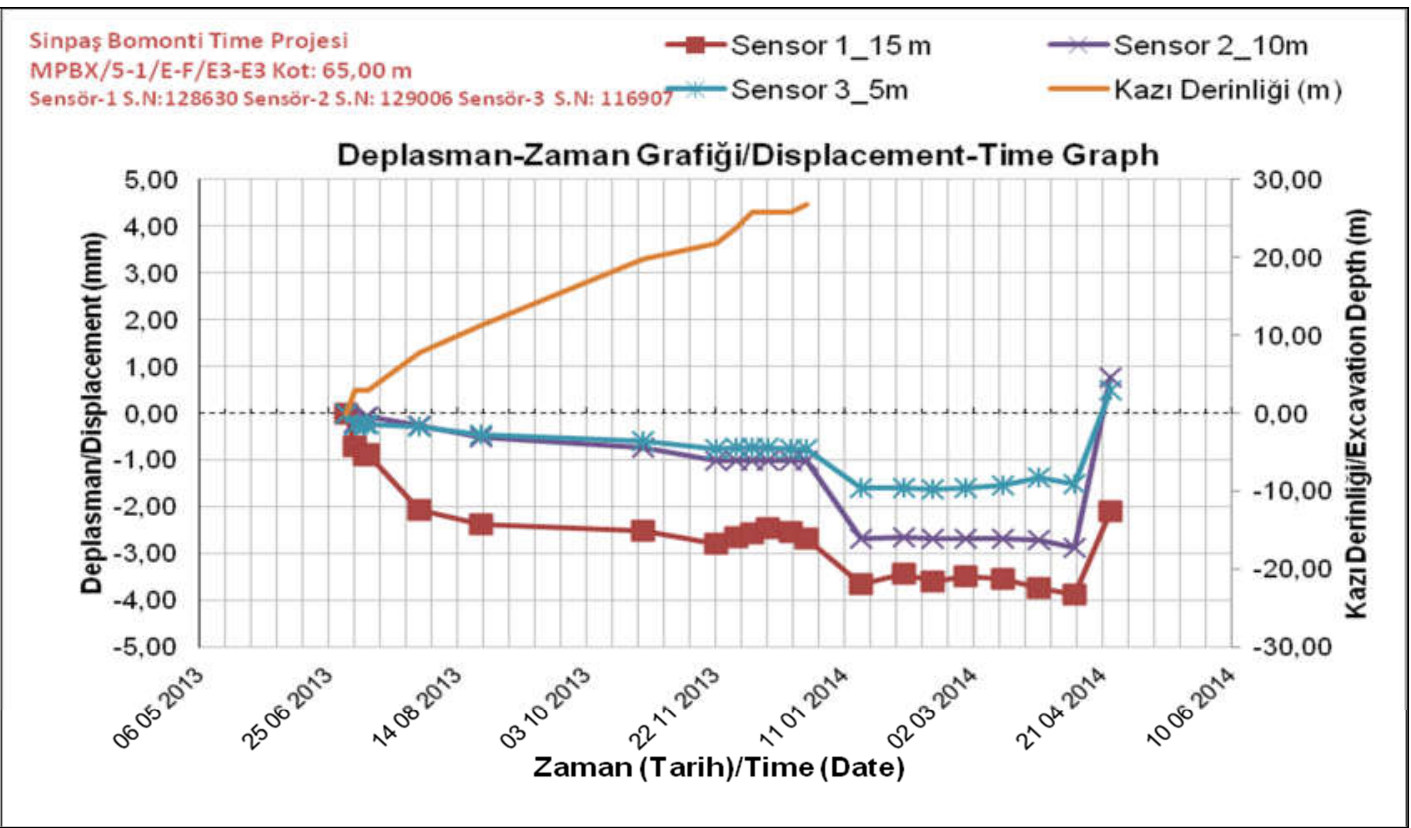

Şekil 13. Ekstansometre verilerinden elde edilen deplasman zaman grafikleri [4] 


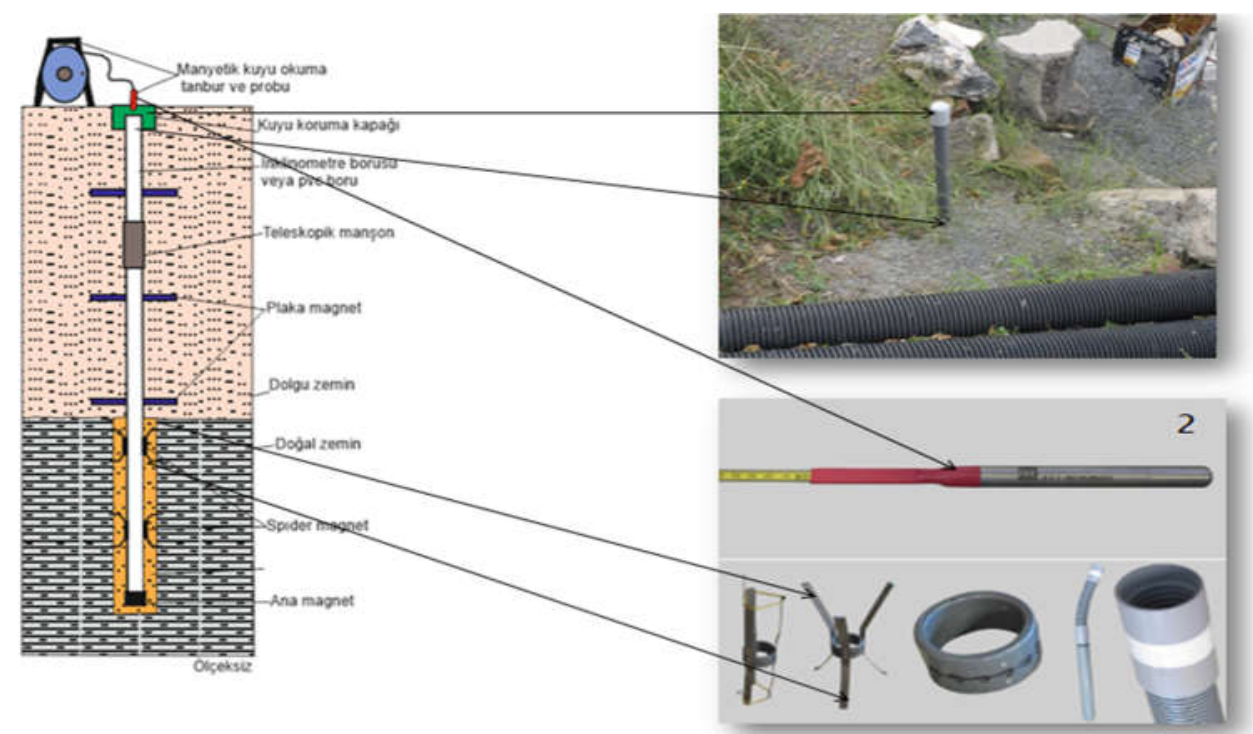

Şekil 14. Manyetik oturma kolonu saha yerleşim planı

\subsection{Piyezometre}

Proje alanında yeraltı suyu değişimlerini ölçmek amaciyla E1, E2, E3, E6, E7, E8, E12 ve E13 kesitlerine her kesitte ikişer adet olmak üzere 8 adet piyezometre kuyusu açılarak piyezometreler yerleştirilmiştir. Yerleştirilen piyezometrelerden ilki kuyu tabanına yakın derinliğe yerleştirilirken ikinci piyezometre kuyunun orta kısmına yerleştirilmişstir. Yerleştirilen piyezometrelerin alt kısımları $1 \mathrm{~m}$ kalınlığında bentonit malzeme ile geçirimsiz bir zon oluşturulmuştur. $1 \mathrm{~m}$ kalınlığında geçirimsiz bentonit zon üzerine $1 \mathrm{~m}$ kalınlığında kum filtre oluşturulduktan sonra jeotekstil ile sarılmış kum filtre içerisindeki piyezometre bu $1 \mathrm{~m}$ 'lik filtre dolgu üzerine temas edecek şekilde düşey doğrultuda tutularak piyezometre çevresi ve üstü $1 \mathrm{~m}$ kum filtre oluşturulacak şekilde filtre işlemi tamamlanmıştır. Filtre yapımı tamamlandıktan sonra tekrar $50 \mathrm{~cm}$ kalınlığında geçirimsiz bentonit zon oluşturulmuştur [2].

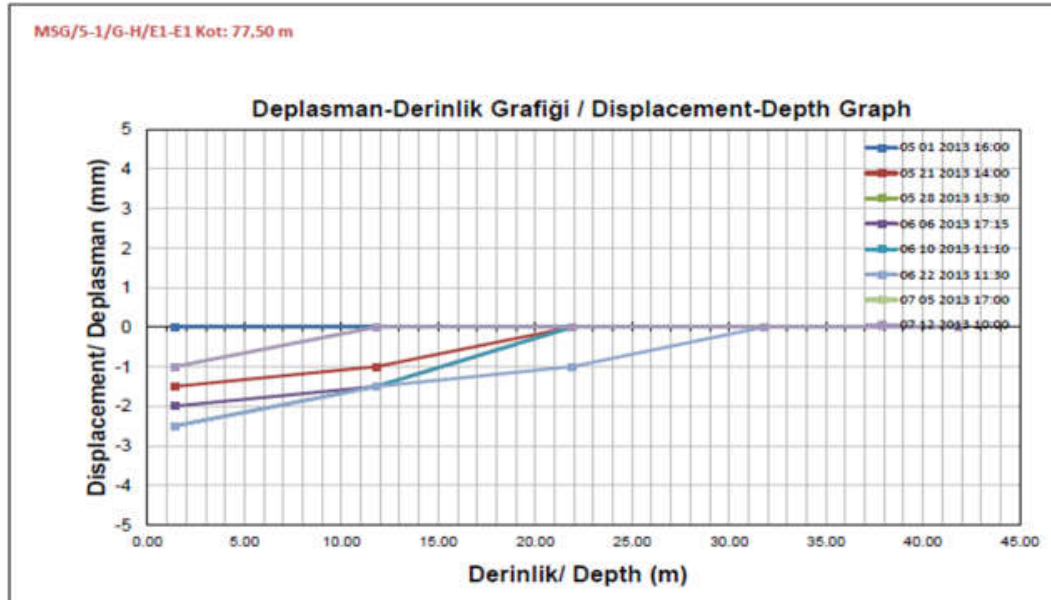

Şekil 15. Manyetik oturma ait yer değiştirme (deplasman) derinlik grafiği 


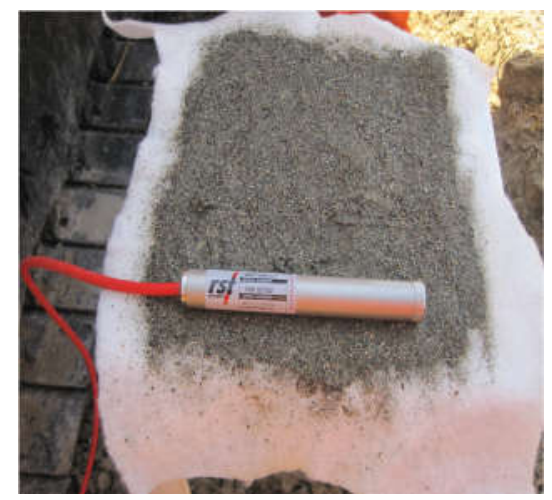

Şekil 16. Piyezometrenin kum filtre ile sarılması

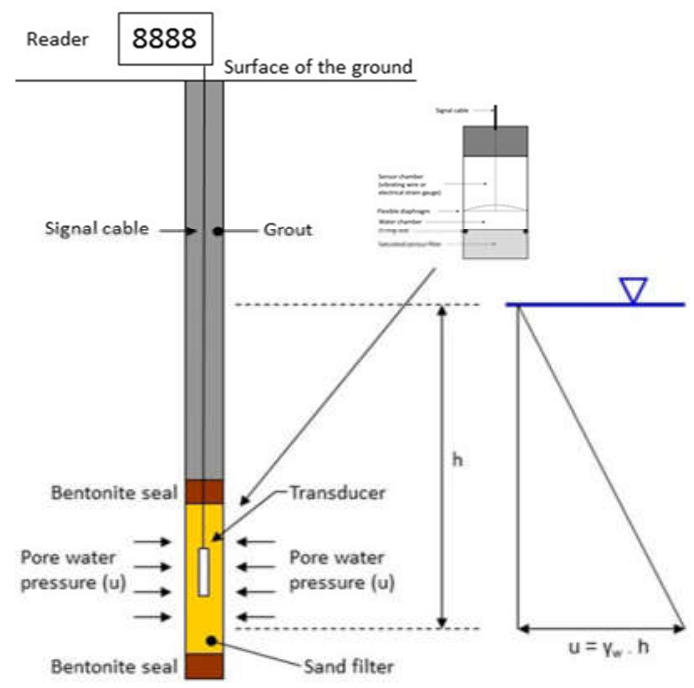

Şekil 17. Piyezometrenin yerleşim şeması

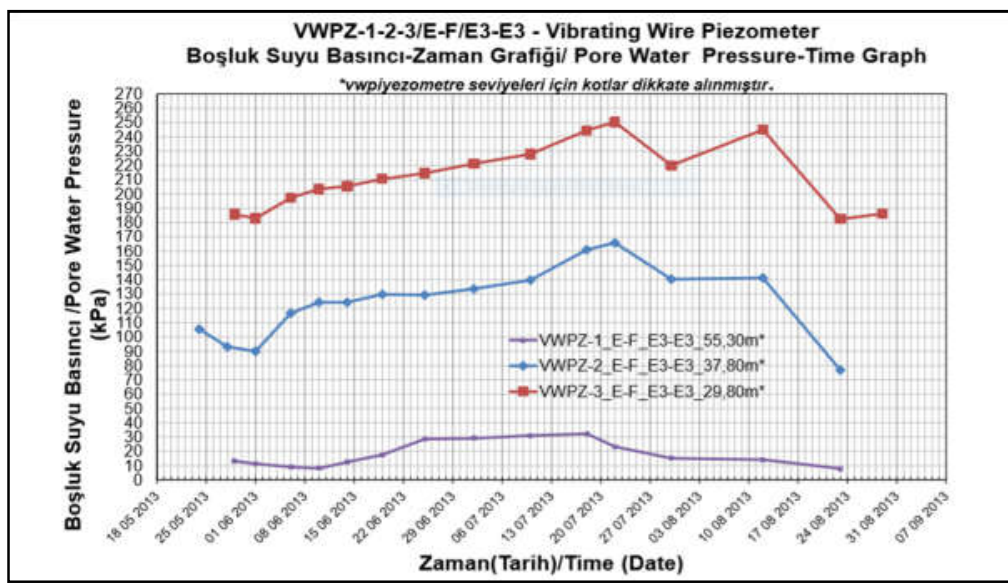

Şekil 17. Boşluk suyu basıncı zaman grafikleri 


\section{ARAŞTIRMA BULGULARI}

Bu çalışma İstanbul İli, Şişli İlçesinde, yer alan çok katlı yapının derin temel kazı çalıșmaları boyunca yürütülen çalışmalarda jeoteknik ölçüm yapmak için kullanılan inklinometre, yük hücresi, piyezometre, ekstansometre ölçüm aletleri ve bu ölçüm aletleri ile yapılan ölçümlerden elde edilen veriler değerlendirilmiştir.

Elde edilen bulgular her bir ölçüm aleti için aşağıda özetlenmiştir.

Proje kapsamında 104 jeoteknik ölçüm aleti yerleştirilerek ölçüm yapılmıştır. 19 adet inklinometre, 54 adet yük hücresi, 14 adet ekstansometre, 3 adet manyetik oturma kolonu, 14 adet piyezometre kullanılmıştır. $\mathrm{Bu}$ ölçüm aletlerinin kullanıldığ ${ }_{1}$ proje alanının temel birimi Paleozoik yaşlı Trakya formasyonundan meydana gelmektedir. Formasyonun başlica birimlerini kumtaşı şeyl ve kil taşları oluşturmaktadır. Bu birimlerin kalınlıkları çalışma sahası boyunca değişiklik göstermektedir. Proje alanının zemin ve mühendislik parametrelerinin belirlenmesi amacıyla 10 adet araştırma sondaj kuyusu açılmıştır. Açılan sondaj kuyularında yeraltı su seviyesine (yass) SK-5 kuyusunda ve SK-11 nolu sondaj kuyusunda 4,5. m'de SK-7 kuyusunda ise 19,3 m’ de ölçülmüştür. Proje alanında yapılan aletsel ölçüm, jeolojik araştırmalar, sondaj çalışmaları, laboratuvar analizleri, teknik hesaplamalar ve gözlemsel araştırmalarla jeoteknik veriler toplanmıştır. $\mathrm{Bu}$ veriler değerlendirilerek derin kazı çalışmalarının yürütülmesinde kullanılan jeoteknik ölçüm aletlerinin şev hareketlerinin aletsel ölçümündeki gerekliliğine değinilmiştir.

\section{1. Ölçüm Verilerine Göre Gözlemlenen Aşırı Yer Değiştirmeler}

Proje alanın E4 kesitinde yer alan tünel cephesinde yüzey sularının etkisi ile ileri derecede bozunmaya uğrayan kumtaşı ve killi birimler içerisinde yapılan temel kazı sonucu yapılan yüzeysel incelemeler ve yerleştirilen ölçüm aletlerinden alınan ölçümler sonucunda kesitteki yatay yer değiştirme miktarının artan kazı derinliğine bağlı olarak problem oluşturacağı kanaatine varılarak kesitte oluşturulan kazı destek sistemi güçlendirilmiştir. E4 kesitinde meydana gelen hareketlilik şeyl birimi içerisinde meydana gelmiştir. Yapılan inklinometre ölçümüne göre kuyu üst ucundan $6 \mathrm{~m}$ derinde meydana gelen yatay yer değiştirme miktarı kazı yönünde $30 \mathrm{~mm}$ olarak ölçülmüştür. Aynı kesitte yer değiştirme öncesi alınan yük hücresi okumas1 498,18 kN iken deplasman sonrası yük miktar1 524,56 kN olarak okunmuştur. İki yük hücresi okuma miktarı arasındaki fark 26,38 kN (2,638t) olarak saptanmıştır. Yapılan yeni ankraj delgileri ve kuşaklı destekleme çalışmaları sonucunda hareket miktarı kontrol altına alınmış, kazı boyunca deplasman miktarının güvenlik sınırları içerisinde kalması sağlanmıştır

\subsection{Jeoteknik Ölçüm Aletlerinin Şev Hareketliliklerinin Ölçülmesinde Birlikte Kullanılması ve Ölçüm Verilerinin Değerlendirilmesi}

İnklinometre: İnklinometere verilerinden çalışma kapsamında elde edilen birden çok grafik yardımı ile şevlerde meydana gelen hareketlilik çok yönlü olarak incelenme imkanı sağlamıştır. Ölçüm hassasiyeti çok yüksek olduğu için E4-E4 kesitinde meydana gelen kütle hareketliliği kütleleri oluşturan yapılar birbirinden kopmadan önceden belirlenmiş ve hareketlilik ciddi boyutlara ulaşmadan önlem alınmıştır. Bir tek okuma seti ile birden çok inklinometre kuyusundan okuma alındığı için kazı boyunca daha avantajlı ve ekonomik ölçümler yapılmıştır.

Yük Hücresi: Yük hücreleri, çalışma kapsamında zemin çivilerine ve ankraj uçlarına belirli yüklerle yüklenerek yerleştirilmiştir. Yerleşim işlemi yapıldıktan sonra bu aletlerden veri toplama işlemi tamamen elektronik ortamda gerçekleştiği için hata payı oldukça az olmuştur. Kişiye bağlı okuma hatası neredeyse hiç olmamıştır. Yük hücrelerinden saha bilgisayarı yardımı ile sahada okuma alınabildiği gibi kablolama yoluyla gerekli görüldüğünde otomatik okuyucu sistemlerine bağlanılarak uzaktan okuma alma avantajı da sağlamıştır. Çalışma kapsamında belirli aralıklarla yerleştirilen yük hücreleri ankraj sistemlerinin birlikte çalışıp çalışmadığı hakkında önemli veriler 
sağlamıștır. Yük hücrelerinden elde edilen grafikler kullanılarak ölçüm sıklığına bağlı olarak kazı derinliği şev hareketliliği ilişkisi sürekli gözlemlenmiştir. Farklı ölçüm disiplinine sahip diğer ölçüm aletleri ile birlikte aynı kesitlerde kullanıldığı için ölçüm aletlerinin ölçüm hassasiyetleri açısından sınıflandırılmasına olanak sağlamıştır.

Ekstansometre: Yatay hareketliliği ölçmek amaciyla E1, E2 ve E3 kesitlerine 14 adet ekstansometere yerleştirilerek ölçümler yapılmıştır. Yapılan ölçümlerle ölçülen en büyük yer değiştirme E2 kesitinde $3,8 \mathrm{~mm}$ olarak ölçülmüştür. Ölçülen bu değer kesit için risk teşkil etmemiştir. Meydana gelen 3,8 mm'lik yer değiştirme ise kazı ile kaldırılan zemin ağırlığına bağlı genleşme hareketi olarak öngörülmüştür.

Manyetik Oturma Kolonu: Proje kapsamında yerleştirilen oturma kolonları yoluyla düşeyde meydana gelen yer değiştirmeler periyodik olarak ölçülmüş, ölçüm verileri diğer ölçüm aletlerinden elde edilen verilerle birlikte analiz edilerek kazı kontrollü bir şekilde sürdürülmüştür. Yapılan ölçümler sonucu çalışma alanında düşey yönde risk meydana getirecek boyutlarda bir oturma ölçülmemiştir.

Piyezometre: Temel kazısı boyunca şev gerisinde açılan sondaj delgilerine yerleştirilen piyezometre ölçümleri ile yeraltı suyu değişimleri gözlemlenerek artan kazı derinliği süresince kütle hareketlerine olan veya olabilecek etkileri düzenli olarak gözlenmiştir. Yeraltı suyu değişimleri mevsimsel yağışlar dışında önemli bir değişkenlik göstermemiştir.

\section{SONUÇLAR}

Yapılan çalışma süresince elde edilen jeoteknik veriler genel olarak değerlendirildiğinde;

Çalışma boyunca aynı kesite yerleştirilen farklı ölçüm disiplinine sahip jeoteknik ölçüm aletleri olan yük hücresi, ekstansometreler ve manyetik oturma kolanları ve piyezometreler birlikte kullanılmış alınan yer değiştirme miktarları yatay ve düșey yönlü olarak yeraltı suları etkisinde ölçülmüştür. Yapılan çok yönlü ölçümler ile meydana gelen yer değiştirmeler inklinometre ile yatayda milimetre olarak ölçülürken, yük hücreleri bu yatay yer değiştirmeye neden olan kütle hareketini $\mathrm{kN}$ birim ile ölçmüştür. Kesitlere yerleştirilen ekstansometreler ise yer değiştirme miktarlarını, bu yer değiştirmenin meydana geldiği noktanın kazı yüzeyi ile olan ilişkisini çeşitli grafikler yardımı ile inceleme olanağı sağlamıştır. Meydana gelen oturma miktarları ise yerleştirilen manyetik oturma kolonları ile ölçülmüştür. Kazı boyunca aynı kesite yerleştirilen farklı jeoteknik ölçüm aletlerinden alınan veriler birlikte analiz edilerek bu veriler 1 şı ğında derinliği 50 metreden fazla olan derin temel kazısı ciddi şev hareketlilikleri yaşanmadan tamamlanmıştır. Yapılan bu çalışma gösteriyor ki derin kazılarda meydana gelen veya gelebilecek kazalar yapılacak jeoteknik ölçümler ile önlenmektedir.

\section{KAYNAKLAR}

1. Özaydın, K., Yıldırım, M., 2000. İstanbul'un Zemin Koşulları ve Geoteknik Sorunlar Yıldız Teknik Üniversitesi İnşaat Fakültesi Bölümü.

2. Keskin, V., 2018. Derin Kazı Temelerde Şev Duraylılığının Aletsel Ölçümü ve Ölçüm Verilerin Değerlendirilmesi. Ç.Ü., Fen Bilimleri Enstitüsü, Yüksek Lisans Tezi, Adana.

3. Keskin, V., Türkmen, S., 2019. Derin Kazılarda Şev Duraylılığının Aletsel Ölçümü ve Ölçüm Aletlerinin Değerlendirilmesi. Ulusal Mühendislik Jeolojisi ve Jeoteknik Sempozyumu, 03-05 Ekim 2019, Denizli.

4. Yüksel, S., Bakılar, G., 2009. Proje Alanı Jeoteknik Etüt ve Sondaj Çalışmaları Temel Etüt Raporu. Elc Group Müş. ve Müh. Ltd. Şti. İstanbul.

5. Keskin, V., Çakar, G., 2015. Sinpaş Bomonti Time Projesi Jeoteknik Enstrümasyon Gözlem Raporları (1-40), Geogrup İnşaat A.Ş., İstanbul.

6. Digital Inclinometer System Rstinstrument Ltd. Digital mems http://www.rstinsrument.com 